\title{
Reefing of Quarter Spherical Ribbon Parachutes used in the Ares I First Stage Deceleration System
}

\author{
Jason R. Schmidt ${ }^{1}$ and Peter G. McFadden ${ }^{2}$ \\ United Space Alliance, LLC, Cape Canaveral, FL, 32920
}

\begin{abstract}
This paper introduces the parachutes that have been drop tested in support of the Ares I first stage deceleration system development. The results of the tests show that the reefing ratios for these quarter spherical ribbon parachutes provide the same reefed drag area as historical conical ribbon parachutes. Two sources are investigated for properly normalizing the parachutes relative to their suspension line length, and one is found to be superior.
\end{abstract}

\section{Nomenclature}

$D \quad=$ nominal diameter of the parachute

$L_{e} \quad=$ equivalent length of a suspension system

\section{Introduction}

$\mathrm{T}_{\mathrm{r}}^{\mathrm{H}}$ HE Ares I first stage deceleration system is being baselined with quarter spherical continuous ribbon parachutes. The Ares I Program is part of the Constellation Program, which has among its many goals, the return of man to the moon. To this point, reliable information on the reefing of quarter spherical ribbon parachutes has been difficult to find. One goal of the Ares I parachute drop test program is to identify an empirical relationship between reefing line length and drag area ratio for the Ares I quarter spherical ribbon parachutes.

Knacke defines the reefing ratio as the ratio of the diameter of the circle that the reefing line in an inflated canopy forms to the nominal diameter. The drag area ratio is defined as the ratio of the reefed drag area to the full open drag area. Often in parachute design, these values are plotted against each other to produce an empirical curve used for reefing line length selection.

One of the oldest and most well known sources of reefing line curves is Figure 5-71 of Knacke's Parachute Recovery Systems Design Manual ${ }^{1}$. Originally published in Ref. 2, Knacke presents data from various sources that reported on flat circular and conical ribbon parachutes, as well as many other shaped solid, ring slot, extended skirt, and ring sail parachutes. Data for conical ribbon parachutes are also available from heritage programs such as the Space Shuttle Program (SSP) Solid Rocket Booster (SRB).

Problems can arise when comparing data among various parachutes if proper care is not taken to normalize the dimensions and drag areas of the parachutes. When SRB reefing ratios were compared to the literature and used in the original predictions for Ares I reefing line lengths, the reefed drag areas did not match up with the published curves. Further investigations showed that the suspension line length was not normalized with the best available data.

The purpose of this paper is to introduce the Ares I developmental parachutes and to compare Ares I quarter spherical ribbon parachute reefing ratio data with conical ribbon parachute data in the literature. Techniques for normalizing parachute reefing data before comparing them to published values are reviewed. The results of Ares I drop tests show that for a variety of canopy sizes and porosities, quarter spherical parachutes tend to agree with the reefing line curve of historical conical ribbon parachutes. State-of-the-art data acquisition hardware also improves the quality of the data, confirming the reliability of historical information for use in future parachute design.

\section{Ares I Test Parachutes}

The Ares I first stage deceleration system consists of a pilot, a drogue, and a cluster of three main parachutes, which are configured in a similar manner to the SSP SRB parachutes. In Ares I flight, the pilot parachute will be permanently reefed to near full open. The drogue will have three reefing stages prior to full open, beginning with a

\footnotetext{
${ }^{1}$ Engineer, Launch \& Recovery Systems - Strength and Fracture, MS USK-841, Member, AIAA.
}

${ }^{2}$ Engineer, Launch \& Recovery Systems - Dynamics and Loads, MS USK-841. 
first stage reefing ratio near $40 \%$ of full open drag area, then proceeding to $60 \%, 80 \%$ and full open drag area. The main parachute cluster will have two reefing stages prior to full open with a first stage reefing ratio approximately $20 \%$, and a second stage near $40 \%$ of full open cluster drag area.

The Ares I pilot and drogue parachutes have geometric porosities of approximately $19.5 \%$ and nominal diameters of 11.5 feet and 68 feet, respectively. The Ares I main parachute tested here has a geometric porosity of $11.5 \%$ and a nominal diameter of 150 feet. In future tests it will have an increased porosity of $15.0 \%$. All three parachutes are of Kevlar construction (nylon is used in the horizontal ribbons and nonstructural members) and utilize vent hoops instead of vent bands to react radial loads at the apex of the canopy. Vent hoops have previously been used in the drogue parachute for the NASA X-38 vehicle ${ }^{3}$, and have been documented in Ref. 4.

As part of the Ares I first stage development, there have been three pilot, two drogue, and two main parachute drop tests at the time of this document. The remaining tests include two main parachute cluster tests, and a design load and overload test of each parachute. In the three completed pilot parachute specific tests as well as in support of the drogue parachute tests, the pilot parachute has been tested with reefing ratios of $75 \%$ to $98 \%$ of full open drag area. In the pilot specific tests, the parachutes were disreefed in flight in order to obtain the appropriate full open drag area for each specific test. Only two pilot parachutes have been manufactured and used in this testing, reducing the variation in drag area measurements due to variations such as those in fabrication.

The two drogue parachute tests investigated reefing ratios between $35 \%$ and $70 \%$ of full open drag area. In each drogue test, reefed drag area data was gathered for the pilot and main parachutes as well. To date, only one drogue parachute has been manufactured for drop testing. However, in the second drop test, the drogue parachute was modified slightly to include additional fullness near the vent. No change in drag area was observed.

The main parachutes have been tested individually in two main parachute specific tests and on the drogue parachute tests with reefing ratios spanning from approximately $20 \%$ to $40 \%$ of full open drag area. One main parachute has been fabricated for use in the test program thus far, which guarantees that scatter in the data is not due to variations in manufacturing.

An overall summary of the parachutes and their tested reefing ratios is shown in Table 1.

\section{Reefing Ratio Development}

Before comparing the Ares I parachute reefing performance data to the literature, it must be normalized to the information in the literature. An effective reefing line length, an asbuilt nominal diameter, and an effective suspension line Table 1. Reefing Ratios in Ares I Drop Tests to Date.

\begin{tabular}{|c|c|c|c|c|c|c|}
\hline \multirow{2}{*}{ Drop Test } & \multicolumn{6}{|c|}{ Reefing } \\
\cline { 2 - 7 } & Pilot & $\begin{array}{c}\text { 1st Stage } \\
\text { Drogue }\end{array}$ & $\begin{array}{c}\text { 2nd Stage } \\
\text { Drogue }\end{array}$ & $\begin{array}{c}\text { 3rd Stage } \\
\text { Drogue }\end{array}$ & $\begin{array}{c}\text { 1st Stage } \\
\text { Main }\end{array}$ & $\begin{array}{c}\text { 2nd Stage } \\
\text { Main }\end{array}$ \\
\hline Pilot Drop Test\#1 & $76.6 \%$ & $\mathrm{x}$ & $\mathrm{x}$ & $\mathrm{x}$ & $\mathrm{x}$ & $\mathrm{x}$ \\
\hline Pilot Drop Test\#2 & $84.1 \%$ & $\mathrm{x}$ & $\mathrm{x}$ & $\mathrm{x}$ & $\mathrm{x}$ & $\mathrm{x}$ \\
\hline Pilot Drop Test \#3R & $98.6 \%$ & $\mathrm{x}$ & $\mathrm{x}$ & $\mathrm{x}$ & $\mathrm{x}$ & $\mathrm{x}$ \\
\hline Main Drop Test \#1 & $\mathrm{x}$ & $\mathrm{x}$ & $\mathrm{x}$ & $\mathrm{x}$ & $19.7 \%$ & $31.2 \%$ \\
\hline Main Drop Test\#2 & $\mathrm{x}$ & $\mathrm{x}$ & $\mathrm{x}$ & $\mathrm{x}$ & $25.1 \%$ & $46.7 \%$ \\
\hline Drogue Drop Test \#1 & $100 \%$ & $39.3 \%$ & $59.4 \%$ & $73.3 \%$ & $19.8 \%$ & $39.2 \%$ \\
\hline
\end{tabular}

length must all be determined. The effective suspension line length is compared to empirical data in the literature to normalize the full open drag area, and the resulting drag area verses reefing ratio curve can be compared to published data. 
The Ares I main and drogue parachutes use reefing rings mounted below the skirt. In order to ensure accurate comparison with the literature, the manufactured length of the reefing line must be corrected for the local geometry of the parachute. When an Ares I canopy is inflated, the diameter of the effective reefing line is in effect larger than the fabricated reefing line. The effective reefing line is equivalent to a reefing line that is sewn to the skirt of the canopy (see Fig. 1). In order to accurately compare the reefing ratios to the literature, the equivalent, or effective,

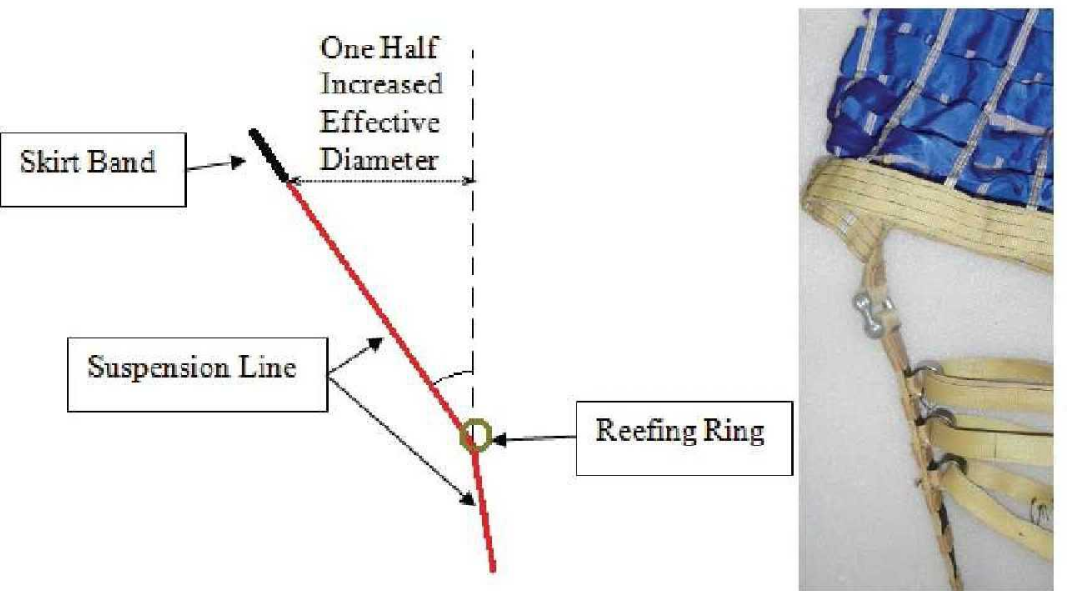

a)

Figure 1. Schematic (a) and photo (b) of drogue parachute reefing line configuration. diameter of the reefing line must be used.

The nominal diameter of the parachute is corrected as well because the reefing ratio is defined using the nominal diameter of the parachute. Sewing take-up and drawing tolerances may change the diameter of the parachute. In order to correct for this, the parachute radial is measured from the vent to the skirt, and the variance in constructed length is used to correct the nominal diameter.

Similarly, the effective length of the suspension lines is determined. The lengths of the suspension lines are extrapolated past the deck fittings or confluence to a point at which the suspension lines would converge (see Fig. 2). This extrapolated length is used to normalize the full open drag area of the parachute for use in determining the drag area ratio.

The reason the suspension lines must be normalized is as follows. When suspension line length increases, the suspension lines become more parallel. This in turn diminishes the inboard force at the skirt of the canopy. As a result, the diameter of the skirt is allowed to expand further, increasing the full open drag area of the parachute. For this reason, several sources have developed empirical curves scaling the full open drag area of a parachute with a given suspension line length to an equivalent parachute with suspension lines equal in effective length to the nominal diameter of the parachute $\left(L_{e} / D\right.$ $=1.0$ ).

In drop testing, the pilot parachute has an effective suspension line to nominal diameter ratio of 1.70 . The effective length of the drogue suspension lines is 1.74 times the nominal diameter of the drogue parachute, and the effective length of the main suspension system is 1.49 (in the drogue tests) and 1.46 (in the main tests) times the nominal diameter of the main parachute.

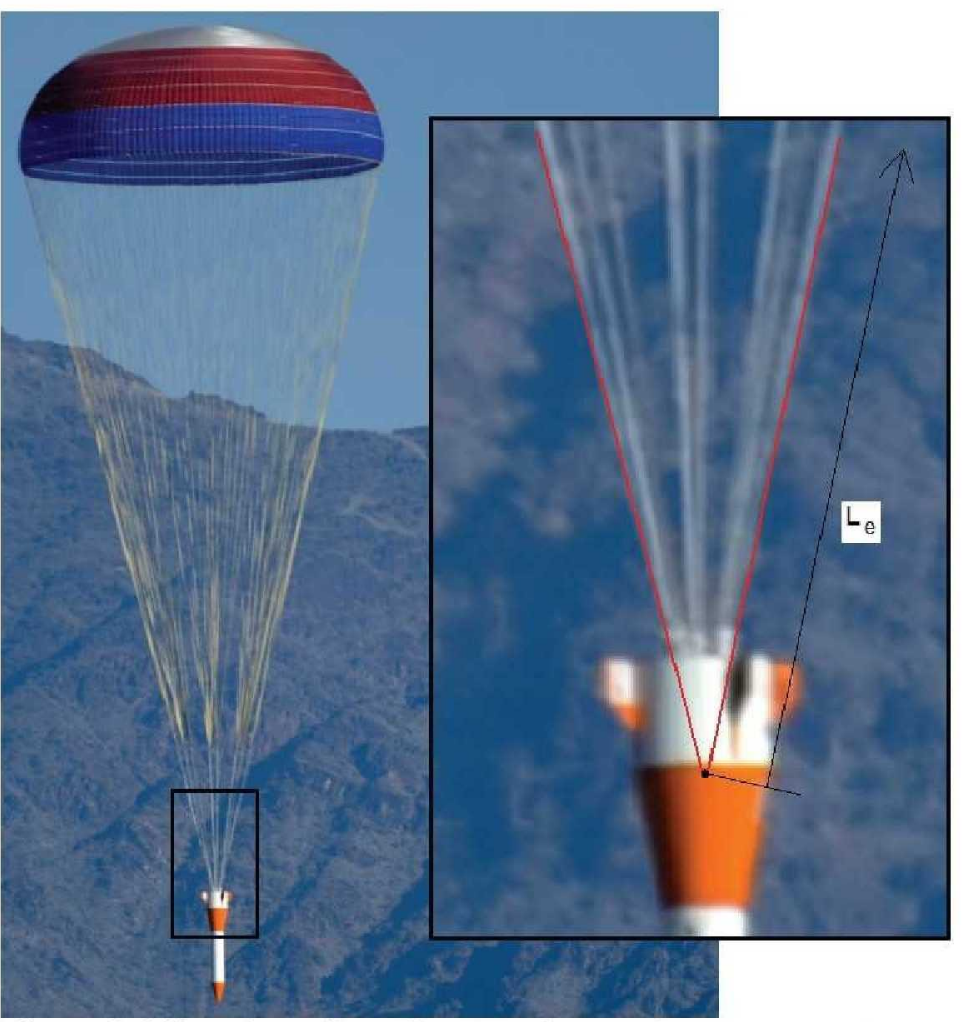

Figure 2. The Ares I main parachute risers converge to a confluence, but the effective length, $L_{e}$, of the suspension system extends into the vehicle. 


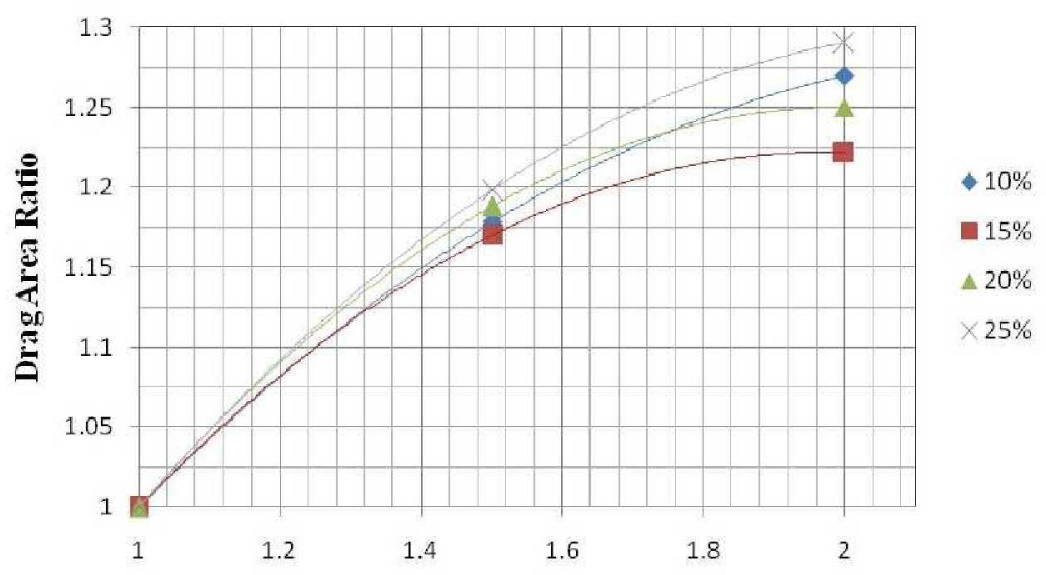

Ratio of Effective Suspension Line Length to Nominal Diameter

Figure 3. Variation of drag coefficient with suspension line length for various geometric porosity conical parachutes ${ }^{5}$.

Knacke has presented a normalization curve in Ref. 1. Wolf provides a curve as well in Ref. 5, which is reproduced in Fig. 3. There is a large difference between the two sources, so both sources were investigated. When the Knacke curve was used, the quarter spherical parachutes appear to lie on a different drag area ratio vs. reefing ratio curve than the conical ribbon parachutes. The use of the Wolf curve to normalize against the suspension line length to nominal diameter ratio, results in a much better agreement between the Ares I test reefing data and historical charts. When normalized with the Wolf curve, the data can be plotted directly in line with those published by Knacke. The Knacke curve results in a reefing ratio curve that is below the published values.

Figure 4 shows the Ares I drop test reefing values plotted alongside conical ribbon data from Knacke ${ }^{2}$. The 2nd

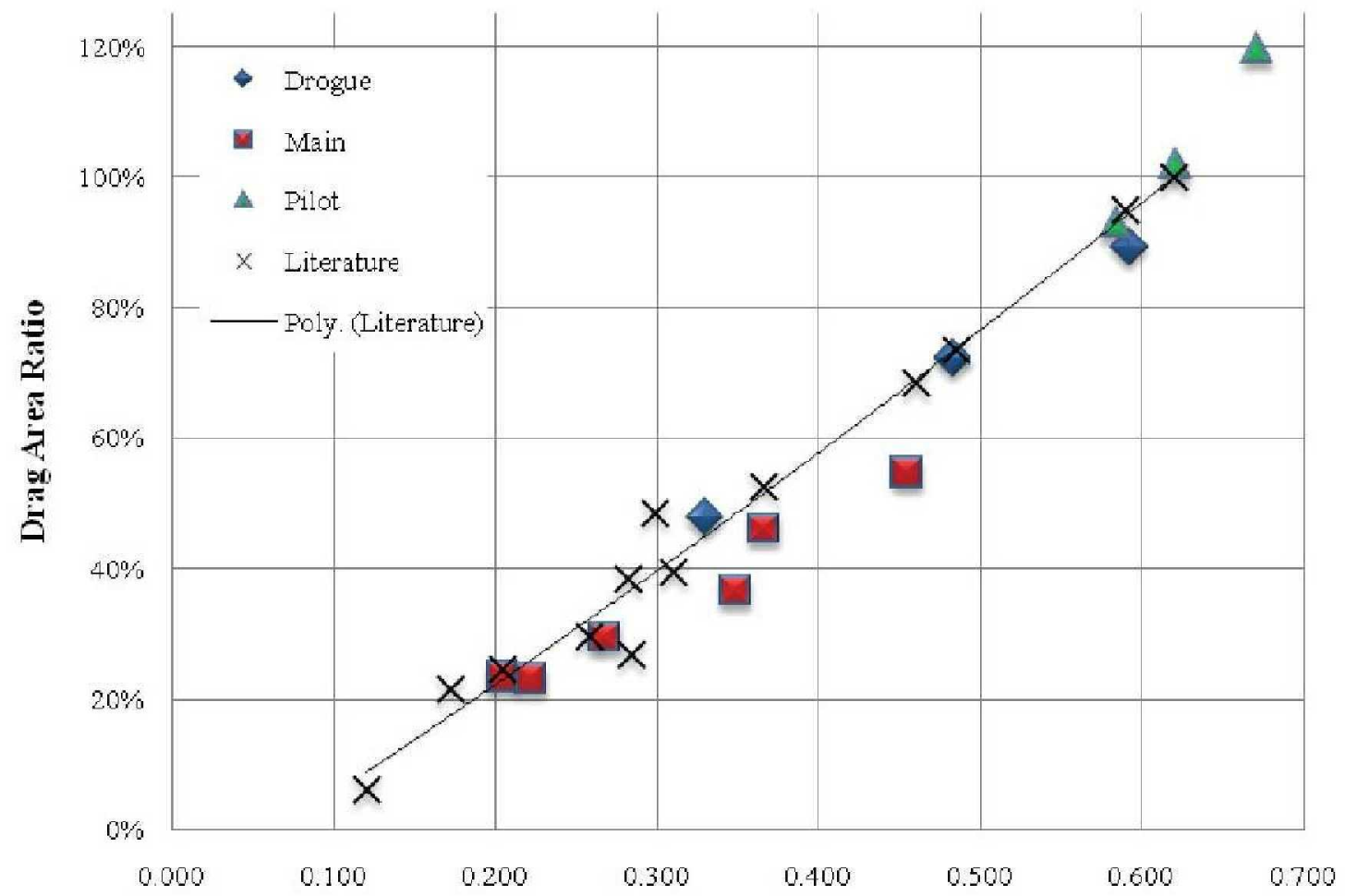

Reefing Ratio

Figure 4. Ares I drop test drag area ratio verses reefing ratio plotted among $\mathrm{Knacke}^{2}$ conical ribbon data

order polynomial trendline was added by the author and fit to the Knacke data only. The values fit well, although there is much dispersion in the data even without the scatter due to variations in parachute manufacturing and with more modern measurement instrumentation. The main parachute values are slightly low, but this may be due, in part, to uncertainties in the full open drag when the main was unstable. 


\section{Conclusion}

The results of Ares I drop tests show that quarter spherical parachutes agree with the reefing line curve of historical conical ribbon parachutes. It shows that the proper suspension line normalization is important and that the data from Wolf $^{5}$ appears to be the most correct. Furthermore, this data covers a variety of ribbon parachutes. It shows that variations in canopy shape, nominal diameter, and porosity cause little if any variation in the reefing curve.

\section{Acknowledgments}

The authors thank Dr. Dean Wolf for his guidance and input throughout the development and testing of the Ares I first stage parachutes. He is truly an essential part of the team. They also acknowledge NASA Marshall Space Flight Center and everyone on the Ares I first stage deceleration subsystem development team who contributed to the immensity of work necessary to prepare for and successfully complete the Ares I drop tests.

\section{References}

${ }^{1}$ Knacke, T. W., Parachute Recovery Systems Design Manual, Para Publishing, Santa Barbara, CA, 1992.

${ }^{2}$ Knacke, T. W., "Reefing of Parachutes-Drag Area Ratios vs Reefing Ratios," Aeronautical Systems Division, ASD-TR-762, Wright-Patterson Air Force Base, OH, July 1976.

${ }^{3}$ Behr, V., Hillebrandt, F. D., Rutledge, B., and Wolf, D. F., 'Development of an 80'-Diameter Ribbon Drogue Parachute for the NASA X-38 Vehicle," 16th ALAA Aerodynamic Decelerator Systems Technology Conference and Seminar, ALAA-20012042, Boston, MA, 2001

${ }^{4}$ Rutledge, B., Hillebrandt, F. D., Heindel, K., and Wolf, D. F., "A textile vent hoop replacement for parachute vent lines," 16th AIAA Aerodynamic Decelerator Systems Technology Conference and Seminar, AIAA-2001-2041, Boston, MA, 2001.

${ }^{5}$ Wolf, D. F., and Croll, R. H., "Wind-Tunnel Measurements of Dynamic Reefing Line Force in Ribbon Parachutes," $J$. Aircraft, Vol. 18, No. 1, 1981. 